\title{
A Comparison of the Effect of Chlorhexidine, Tap Water and Normal Saline on Healing Wounds
}

\author{
Comparación del Efecto de Clorhexidina, Agua Corriente y Suero Salino en Curación de Heridas
}

\author{
Ayodeji A. Salami; Innocent O. Imosemi \& Olatunde O. Owoeye
}

SALAMI, A. A.; IMOSEMI, I. O. \& OWOEYE, O. O. A comparison of the effect of chlorhexidine, tap water and normal saline on healing wounds. Int. J. Morphol., 24(4):673-676, 2006.

SUMMARY: Many researchers have advocated in recent times that antiseptic use in healing wounds should be discouraged. Antiseptics have been found to retard healing of wounds. Innocuous solutions like normal saline and tap water are being considered as better alternatives to antiseptics. Chlorhexidine, a commonly used antiseptic, is known to be less toxic on granulation cells. We decided to compare the effect of chlorhexidine, normal saline and tap water on healing wounds.

Three groups of wistar rats had 2 by $2 \mathrm{~cm}$ full thickness wounds made on their right dorsolateral flanks. The wounds were dressed with either chlorhexidine, normal saline or tap water. Wounds were examined at three-day intervals and measurements of area covered were taken on the first day of study and the ninth day. Wound contraction on the ninth day and number of days for healing to take place in the different groups was taken and statistical analysis using student t-test was done to compare the values. Gross morphology of the wounds was also observed.

The result showed an inhibitory effect of chlorhexidine on healing wounds. The wound contraction in the antiseptic group was less than the tap water and saline group on day nine. The average number of days for wound healing to be completed in the antiseptic group was more than the other two. These results were statistically significant when compared with the other two groups. There was no statistical difference in the wound contraction values and rate of healing of the saline and tap water dressed wounds. Grossly, all the wounds dressed with antiseptic also had greenish exudates on their surface by day nine with pale looking granulation tissue, and there was greater mortality in this group.

KEY WORDS: Chlorhexidine; Tap water; Nomal saline; Wound.

\section{INTRODUCTION}

The use of antiseptics in wound disinfections came to being from the work of Joseph Lister in 1865 that first used carbolic acid to treat a wound resulting from a compound fracture (Badoe, et al., 1994). Since then many different antiseptic agents have been employed in the fight against wound microbes with different degrees of effectiveness. In recent times the use of antiseptics has generated a lot of controversy as studies have shown that they are detrimental to wound healing (Drosou et al., 2003). Many of the studies were carried out on tissue culture and have had conflicting results with those done on live animals (Tatnall et al., 1991).

One of the antiseptics involved in this controversy is chlorhexidine, a biguanide, which is known to be less toxic to tissues and has high antibacterial activity against both grampositive and gram-negative bacteria including some fungi and viruses (Sibbald et al., 2000 and Crest, 1998). Although its toxicity level is higher than saline it is still recommended for cleansing and dressing of wounds (Sibbald et al.; Morgan, 1999 and Rodeheaver, 1997). Chlorhexidine causes damage to new tissues and should not come in contact with the meninges and mucous membranes as this can cause permanent damage. Its antimicrobial efficacy is not total, as certain microbes are known to grow in the solution; of note in this regard is Pseudomonas aeruginosa and Proteus mirabilis(Crest).

Physiological saline is a widely recommended irrigating and wound dressing solution, as it is known to be compatible with human tissue ((Sibbald et al.; Morgan; Crest; Edmonds et al., 2004 and Jacobson, 2004). It causes no damage to new tissue and does not affect the functions of fibroblast and keratinocytes in healing wounds. Its effectiveness in preventing infection has not been ascertained (Morgan). 
Tap water is a wound cleaning agent that is becoming increasingly recommended (Crest). Sterile water and saline are comparable in their effects on healing wounds and both are presently being viewed as probably close to the ideal for wound irrigation (Sibbald et al. and Crest). The main difficulty with the use of tap water is ascertaining the source, sterility (Sibbald et al.) and differences in purification procedures in many countries (Whaley).

Although many authorities have concluded that antiseptics are detrimental to wound healing, several other workers have disagreed with this view. The main basis of their argument is that most of the work on wound tissue that suggested the detrimental effect of antiseptics has been invitro studies that did not corroborate in-vivo studies (Drosou et al. Tatnall et al., has shown that a lot of the cytotoxicity exhibited by antiseptics in in-vitro studies on wound tissue were due to differences in concentration of serum to antiseptics and period of exposure to the agent affected the toxicity significantly (Tatnall et al.). Presently many authorities now recommend cautious use of antiseptics due to the different point of views that are prevailing (Morgan and Crest).

In view of this controversy, in-vivo studies on healing wound tissue have become necessary to determine the relevance of antiseptics in clinical usage. It has also become imperative to determine the best agent to use in dressing wounds. Based on this, in this study, we decided to compare the effect of three different wound dressing agents on clean healing wounds by examining the rate of wound contraction, rate of healing and gross morphology.

\section{MATERIAL AND METHOD}

Twenty five adult male wistar rats were obtained from the central animal house of the college of medicine and acclimatized in our laboratory over a period of one week before commencing the study. The rats were fed on standard mice cubes, from Ladokun feeds, and water ad libitum. All animals had humane care that was in compliance with the guidelines for the care and use of laboratory animals of the National Institute of Health.

The animals were placed into three groups; an antiseptic group with nine animals, a tap water group with eight animals and a physiological saline group with eight animals to serve as the control group. The rats were anesthetized with chloroform and a full thickness wound measuring $2 \mathrm{~cm}$ by $2 \mathrm{~cm}$ was made on their right dorsolateral flanks after the area had been shaved and cleaned with $70 \%$ alcohol. The antiseptic group had their wounds irrigated with $0.05 \%$ chlorhexidine (Purit from Chemical and allied products limited, CAPL) and subsequently covered with sterile gauze, adhesives zinc oxide tape was then placed circumferentially around the animal to hold the edges of the gauze. The wounds in the tap water group were irrigated with normal tap water and covered as in the first group. The control group had their wounds also irrigated with physiological saline and then covered like the other groups. Each animal had his wound opened and fresh dressings applied at three-day intervals. The state of the wound was examined during each dressing session. Wounds were measured on the first and ninth days of the study according to the method described by Osuagwu et al. (2004). Animals were observed till wound surfaces were totally epithelized. The statistical analysis was done by comparing the means of the wound measurements using student-t test.

\section{RESULTS}

The study showed a distinct inhibition of wound healing by the chlorhexidine solution. This inhibition was apparent by the ninth day, as shown in Tables I and II, with retarded wound contraction in animals treated with the antiseptic when compared with control and the tap water treated wounds. There was also prolonged mean time of healing in this group. Comparison of the rate of wound contraction and mean number of days for wounds to heal between the antiseptic group and the other two groups was statistically significant.

Wound infection occurred on all the wounds dressed with antiseptic solution. The wounds had greenish exudates on their surfaces by day (Edmonds et al.). The granulation tissue appeared pale. The animals were cachectic and three of them died prior to the final healing of their wounds.

At the end of the study, wounds treated with tap water and physiological saline had good granulation tissue and healed normally. There was no significant statistical difference in any of the parameters in these two groups, as is shown in Table III. Mean wound contraction on day nine was only slightly better in the saline group than in the tap water group. Mean number of days for healing of wounds was also slightly better in the saline group.

There was no mortality in the tap water and saline group as all the animals tolerated the procedure very well. There was no sign of infection in any of the wounds and the granulation tissue in the wounds of the animals of both tap water and saline groups were pink and bled easily. 
Table I. The effect of chlorhexidine and tap water on wound contraction and healing.

\begin{tabular}{lccc}
\hline & Chlorhexidine & Tap water & p-value \\
Mean wound size on day 0 $\left(\mathrm{cm}^{2}\right)$ & $2.98 \forall 0.123$ & $3.16 \forall 0.335$ & 0.481 \\
Mean wound size on day 9 $\left(\mathrm{cm}^{2}\right)$ & $2.22 \forall 0.191$ & $1.35 \forall 0.262$ & 0.018 \\
Percentage wound contraction on day $9(\%)$ & $26.25 \forall 5.59$ & $58.67 \forall 4.99$ & 0.003 \\
Mean number of days for wounds to heal & $27 \forall 0.96$ & $17 \forall 0.59$ & 0.001 \\
\hline
\end{tabular}

Value $=$ mean " standard error of mean; $\mathrm{p}$-value, $\mathrm{p}<0.05$ is significant.

Table II. Comparison of the effect of chlorhexidine and physilogical saline on wound contraction and healing.

\begin{tabular}{lccc}
\hline & Chlorhexidine & Saline & p-value \\
Mean wound size on day $0\left(\mathrm{~cm}^{2}\right)$ & $2.98 \forall 0.123$ & $3.20 \forall 0.256$ & 0.351 \\
Mean wound size on day $9\left(\mathrm{~cm}^{2}\right)$ & $2.22 \forall 0.191$ & $1.08 \forall 0.167$ & 0.003 \\
Percentage wound contraction on day 9 $(\%)$ & $26.25 \forall 5.59$ & $66.17 \forall 4.43$ & 0.000 \\
Mean number of days for wounds to heal & $27 \forall 0.96$ & $16 \forall 0.33$ & 0.000 \\
\hline
\end{tabular}

Value $=$ mean " standard error of mean; $\mathrm{p}$-value, $\mathrm{p}<0.05$ is significant.

Table III. Comparison of the effect of tap water and physilogical saline on wound contraction and healing.

\begin{tabular}{lccc}
\hline & Tap water & Saline & p-value \\
Mean wound size on day $0\left(\mathrm{~cm}^{2}\right)$ & $3.16 \forall 0.335$ & $3.20 \forall 0.256$ & 0.351 \\
Mean wound size on day $9\left(\mathrm{~cm}^{2}\right)$ & $1.35 \forall 0.262$ & $1.08 \forall 0.167$ & 0.003 \\
Percentage wound contraction on day $9(\%)$ & $58.67 \forall 4.99$ & $66.17 \forall 4.43$ & 0.000 \\
Mean number of days for wounds to heal & $17 \forall 0.59$ & $16 \forall 0.33$ & 0.000
\end{tabular}

Value $=$ mean " standard error of mean; $p$-value, $p<0.05$ is significant.

\section{DISCUSSION}

Although the capacity of the skin to heal itself is large, restrictions on this ability include dryness of the wound surface and infections (Smith, 2005). Physiological saline showed better wound healing effect than non-physiological tap water and an antiseptic in this study as is shown in table two. This corroborates the work of Buffa et al. (1997) who showed that canine fibroblast had more damage with tap water than with normal saline. Other workers have documented this effect of normal saline on healing wounds but the mechanism of this effect is presently not known (Jacobson and Lineaweaver et $a l ., 1985)$. Probably the ability of normal saline in keeping the wound surface moist and not affecting the healing process, as it is a physiological solution, may be responsible. This may explain the reason for the slightly better result of the wounds treated with normal saline compared with that of tap water. Griffiths et al. (2001) also found no statistical difference in wounds irrigated with normal saline and tap water.

From this study, tap water has a better effect on wounds than the antiseptic agent and showed no statistical difference between it and normal saline. In table II, the number of days for wounds dressed with normal saline and that of tap water to heal is almost the same. Wound contractions in this two are only slightly different from each other. This might indicate that the mechanism by which this two act on the wound are the same. The only problem to the effective utilization of tap water in cleaning wounds is ascertaining the source and its degree of sterility. The alternative is the use of sterile water that will be safer and more universal (Griffiths et al.).

The wounds dressed with antiseptic in this study deteriorated rapidly several days after the trauma. All of them had greenish exudates, which may indicate pseudomonas spp. (Sibbald et al.). Chlorhexidine is known to allow the growth of Pseudomonas aeruginosa and Proteus mirabilis and it is possible that the stock antiseptic solution had been contaminated with bacteria, which will explain the reason for all the antiseptic treated wounds developing this infection (Crest).

The presence of non-physiological agents act as a wound deterrent in healing as this study has demonstrated (Sibbald et al.). The antiseptic disrupts the migration of the fibroblast and their proliferation. The presence of microbes in the wound which were probably brought by the antimicrobial agent further contributed to the delayed healing seen in the antiseptic treated cases and also worsened the general state of the animals.

Although chlorhexidine is useful in disinfecting intact skin and cleaning dirty traumatized wounds, these agents should not be used on clean healing wounds. Their effect on the healing wound can further cause increased morbidity for the patient. 
SALAMI, A. A.; IMOSEMI, I. O. \& OWOEYE, O. O. Comparación del efecto de clorhexidina, agua corriente y suero salino en curación de heridas. Int. J. Morphol., 24(4):673-676, 2006.

RESUMEN: En la actualidad, diversos investigadores han propagado que el uso de antisépticos en heridas en cicatrización debería, ser abandonado. Se ha encontrado que los antisépticos retardan la cicatrización. Soluciones inocuas, tales como, suero salino y agua corriente, están siendo consideradas como mejores alternativas para efectos antisépticos. La clorhexidina, un antiséptico comúnmente usado, es conocida por ser menos tóxica sobre las células granulares. Basado en lo anterior, comparamos los efectos de la clorhexidina, suero salino y agua corriente en heridas en cicatrización.

A tres grupos de ratas Wistar se les infirió heridas de 2 x $2 \mathrm{~cm}$ de grosor, en su flanco dorsolateral derecho. La heridas fueron cubiertas (pinceladas) con clorhexidina, solución salina o agua corriente, según el caso. Estas heridas fueronn examinadas cada tres días y las mediciones del área cubierta fueron registradas desde el primero al noveno día. La contracción de la herida al noveno día y el número de días que llevó para cicatrizar se regsitraron en los diversos grupos, analizando los resultados esatadísticamente, usando el test t- student para comparar los valores. La morfología macroscópica también fue observada.

Los resultados mostraron un efecto inhibidor de la clorhexidina sobre la cicatrización. La contracción de la herida en el grupo con antiséptico fue menor que en los grupos con suero salino y agua corriente. El promedio de días para cicatrizar, fue mayor en el grupo con antiséptico. Estos resultados fueron estadísticamente significativos al compararlos con los otros dos grupos. No hubo diferencias estadísticamente significativas en los valores de contracción de la herida y rango de cicatrización en el grupo tratado con suero salino normal y en el con agua corriente. Desde el punto de vista macroscópico, las heridas tratadas con el antiséptico también tuvieron un exudado verdoso sobre su superficie al día noveno con un tejido granular pálido y hubo mayor mortalidad en este grupo.

PALABRAS CLAVE: Clorhexidina; Agua corriente; Suero salino; Herida.

\section{REFERENCES}

Badoe, E. A.; Archampong, E. Q. \& Jaja, M. O. A. principles and practice of surgery including pathology in the tropics. $2^{\text {nd }}$ edition. Assemblies of God Literature Center Ltd., 1994.

Buffa, E. A.; Lubbe, A. M.; Verstraete, F. J. \& Swaim, S. F. The effects of wound lavage solutions on canine fibroblasts: an in vitro study. Vet Surg., 26(6): 460-6, 1997.

Crest. General principles of wound care. Recommendations for practice. October 1998. www.n-i.nhs.uk/CREST

Drosou, A.;Falabella, A. \& Kirsner, R. S.. Antiseptics on Wounds. An Area of Controversy. Wounds, 15(5):149-66, 2003.

Edmonds, M.; Foster, A. V. M. \& Vowden, P. Wound bed preparation for diabetic foot ulcers. European wound management association (EWMA). Position document: Wound bed preparation in practice. London: MEP Ltd., 2004.

Griffiths, R. D.; Fernandez, R. S. \& Ussia, C. A. Is tap water a safe alternative to normal saline for wound irrigation in the community setting? J. Wound Care, 10 (10):407-11, 2001.

Jacobson, S. The wrong solution. Emerg. Med., 36(8):13, 2004.

Lineaweaver, W.; McMorris, S.; Soucy, D. \& Howard. R. Cellular and bacterial toxicities of topical antimicrobials. Plast. Reconstr. Surg., 75:394-6, 1985.

Morgan, D. A. Wound management products in the Drug Tariff. The Pharmaceutical J., 263(7072):820-5, 1999.

Osuagwu, F. C.; Oladejo, O. W.; Imosemi, I. O.; Aiku, A.; Ekpo, O. E.; Salami, A. A.; Oyedele, O. O. \& Akang E. E. U. Enhanced wound contraction in fresh wounds dressed with honey in Wistar rats (Rattus norvegicus). West African J. of Medicine. 23:2, 2004.

Rodeheaver, G. T. Wound cleansing, wound irrigation, wound disinfection. In: Krasner D, Kane D. Chronic Wound Care: A Clinical Source Book for Healthcare Professionals, $2^{\text {nd }}$ edition. Wayne, PA. Health Management Publications, Inc., 97-108, 1997.

Sibbald, R.; Williamson, G. D.; Orsted, H.; Campbell, L. K.; Keast, D.; Krasner, D. \& Sibbald, D. Preparing the wound bed debridement, bacterial balance, and moisture balance. Ostomy/ Wound Management., 46(11):14-35, 2000.

Smith, R. G. Wound care product selection. U. S. pharmacist, 30:8, 2005.

Tatnall, F. M.; Leigh, I. M. \& Gibson, J. R. Assay of antiseptic agents in cell culture: conditions affecting cytotoxicity. J. Hosp. Infect., 17(4):287-96, 1991.

Whaley, S. Tap water or normal saline for cleansing traumatic wounds? British J. Community Nursing, 9(11):471-8, 2004.

Correspondence to:

Dr. Ayodeji A. Salami

Department of Anatomy

University of Ibadan

$\mathcal{N I G E R I A ~}$

Pfone: +2348057072670 .

Email: ayodejisalami@gmail.com

Received: 24-05-2006

Accepted: 28-09-2006 